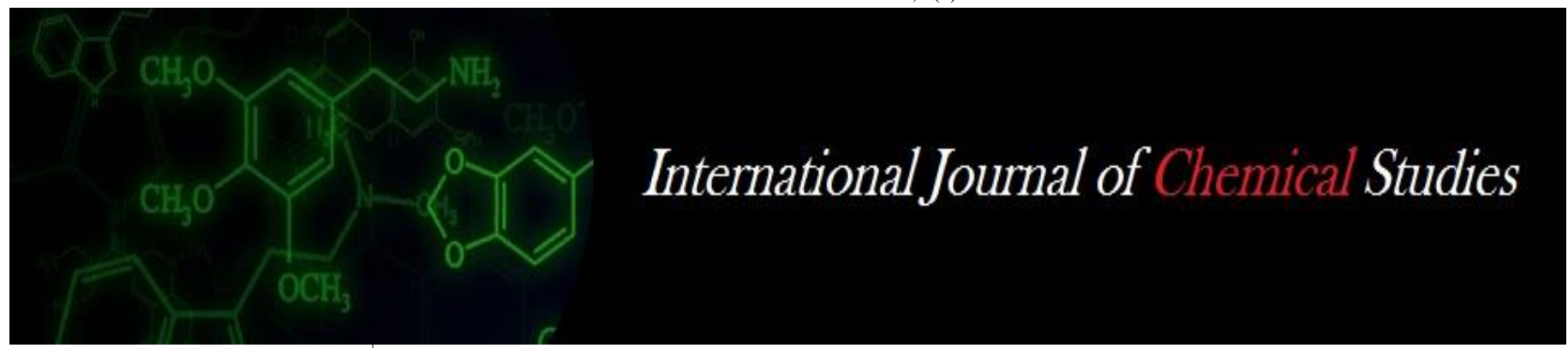

P-ISSN: 2349-8528

E-ISSN: 2321-4902

www.chemijournal.com

IJCS 2020; 8(4): 2859-2862

(C) 2020 IJCS

Received: 22-05-2020

Accepted: 24-06-2020

Surpam TB

Subject Matter Specialist (Agril

Engg.), Krishi Vigyan Kendra,

Khamgaon, Vasantrao Naik

Marathwada Krishi Vidyapeeth,

Parbhani, Maharashtra, India

Pardeshi IL

Professor, Post Graduate

Institute of Post-Harvest

Management, Killa, Roha

Dr. Balasaheb Sawant Konkan

Krishi Vidyapeeth, Dapoli,

Maharashtra, India
Corresponding Author: AP Jadhav

Subject Matter Specialist (Agril.

Engg.), Krishi Vigyan Kendra,

Khamgaon, Vasantrao Naik

Marathwada Krishi Vidyapeeth,

Parbhani, Maharashtra, India

\section{Determination of engineering properties of pearl millet (Bajra)}

\section{Surpam TB and Pardeshi IL}

DOI: https://doi.org/10.22271/chemi.2020.v8.i4ah.10080

\section{Abstract}

The engineering properties of Pearl millet (Pennisetum glaucum) were determined at moisture content of $9.066 \pm 0.078 \%$ (wb). The mean values obtained for length, width and thickness were 3.522, 2.590 and $2.100 \mathrm{~mm}$, respectively. The average value for geometric mean diameter, sphericity, weight of thousand grains, bulk density, true density and porosity were $2.511 \mathrm{~mm}, 0.676,9.896 \mathrm{~g}, 852.644 \mathrm{~kg} . \mathrm{m}-3,1267.236$ kg.m-3 and $32.716 \%$ respectively. The angle of repose mean value was 38 . The co-efficient of static friction on three types of structural material was found to be ranging from 0.378 (steel sheet), 0.422 , (galvanised iron sheet) and 0.426 (card board).

Keywords: Pearl millet, physical properties, aerodynamic properties, frictional properties, mechanical properties

\section{Introduction}

Pearl millet (Pennisetum glaucum) is the most widely grown type of millet. It has been grown in Africa and the Indian subcontinent since prehistoric times. The center of diversity, and suggested area of domestication, for the crop is in the Sahel zone of West Africa. Recent archaeobotanical research has confirmed the presence of domesticated pearl millet on the Sahel zone of northern Mali between 2500 and 2000 BC. ${ }^{[17]}$ Cultivation subsequently spread and moved overseas to India. The earliest archaeological records in India date to around $2000 \mathrm{BC},{ }^{[4]}$ and it spread rapidly through India reaching South India by $1500 \mathrm{BC}$, based on evidence from the site of Hallur. Cultivation also spread throughout eastern and southern parts of Africa. Pearl millet is widely grown in the north eastern part of Nigeria (especially in Borno and Yobe states). It is a major source of food to the local villagers of that region. The crop grows easily in that region due to its ability to withstand harsh weather conditions like drought and flood. Records exist for cultivation of pearl millet in the United States in the 1850s, and the crop was introduced into Brazil in the 1960s.

With ovoid grains of $3-4 \mathrm{~mm}$ length pearl millet has the largest kernels of all varieties of millet (not including [sorghum]) which can be nearly white, pale yellow, brown, grey, slate blue or purple. The 1000 -seed weight can be anything from 2.5 to $14 \mathrm{~g}$ with a mean of $8 \mathrm{~g}$. Pearl millet is well adapted to growing areas characterized by drought, low soil fertility, and high temperature. It performs well in soils with high salinity or low $\mathrm{pH}$. Because of its tolerance to difficult growing conditions, it can be grown in areas where other cereal crops, such as maize or wheat, would not survive. Pearl millet is a summer annual crop well-suited for double cropping and rotations. Today pearl millet is grown on over $260,000 \mathrm{~km}^{2}$ of land worldwide. It accounts for approximately $50 \%$ of the total world production of millets. ${ }^{[10]}$

Recently more productive varieties of pearl millet have been introduced, enabling farmers to increase production considerably ${ }^{[2]}$.

To combat the problem of micronutrient malnutrition in Africa and Asia, a study of serving iron-biofortified pearl millets which is bred conventionally without genetic modification to a control group is proved to have higher level of iron absorbance by the group. ${ }^{[1]}$

The most widely grown millet is pearl millet, which is an important sized crop in India and parts of Africa. Finger millet, proso millet, and foxtail millet are also important crop species. In the developed world, millets are less important. 
Pearl millet crop has a wide adaptability to local environments. Pearl millet is a hardy crop and can grow in areas very hot and dry and on soils too poor for sorghum. Pearl millet is considered more efficient in utilization of soil moisture and has a higher level of heat tolerance than even sorghum and maize. In India, during 2017-18 about 7.38 million ha area was covered under pearl millet with production 9.13 million tonnes and yield $1237 \mathrm{~kg} / \mathrm{ha}$. The states of Rajasthan (4.24 million ha), Maharashtra (0.68 million ha), Uttar Pradesh (0.93 million ha), Haryana (0.45 million ha), Madhya Pradesh (0.31 million ha), Karnataka (0.23 million ha) and Gujarat ( 0.40 million ha) are the major producers of pearl millet in India. The production and yield for Maharashtra was 0.61 million tonnes and $903 \mathrm{~kg} / \mathrm{ha}$. (Source: Directorate of Economics and statistics, DAC \& FW) Knowledge of the engineering properties is important, useful and necessary in the design of processes, machines, structures and controls. These properties are used in analyzing and determining the efficiency of the machine and operation or process as well as determining quality or studying the behaviour of the product during agricultural processing unit operations. Basic information on these engineering properties is of great importance and help engineers towards efficient process and equipment development. The physical properties such as size, shape, surface area, volume, density, porosity, color and appearance are important in designing particular equipment or determining the behaviour of the product for its handling.

Basic information on these engineering properties is of great importance and help engineers towards efficient process and equipment development. The engineering properties like size, shape, geometric mean diameter, surface area, volume, sphericity, 1000 seed mass, true density, bulk density, porosity, angle of repose, coefficient of static friction, coefficient of internal friction, hardness and terminal velocity for different millets at different moisture content have been studied and determined by many researchers (Balasubramanian and Vishwanathan, 2010; Ojediran et al. 2010; Swami and Swami, 2010; Singh et al., 2010; Ramappa et al., 2011) [1, 8, 17, 15, 16]. In 2011, Periera et al. have determined the physical properties of sorghum at a moisture range of 12 to $30 \%(\mathrm{db})$. Tippeswamy, 2006 has determined some of the engineering properties of sorghum (SIA 2642 variety). The properties of the millets vary with varietal difference, moisture content and agronomical conditions it is grown (Konak et al., 2002), which may result in significant variation in the processing of the millets. Hence, the objective of this study was to determine engineering properties of Sorghum- HMT 1001 variety at $11.67 \pm 0.078 \%$ (wb) moisture content.

\section{Materials and Methods}

The experiments were carried out at the Department of Agricultural Process Engineering, Dr. Panjabrao Deshmukh Krishi Vidyapeeth, Akola. The local variety of pearl millet was procured from the local market. The important engineering properties studied were: physical properties (Longitudinal and lateral diameter, shape, colour, true \& bulk density, porosity and weight of 1000 grains), frictional properties (Angle of repose and coefficient of friction) for pearl millet.

\section{Determination of Physical Properties}

Shape and size: The size of the sorghum grain was determined by measuring the linear dimensions - length (L), width (W) and thickness (T) measured using a digital calliper having the least count of $0.01 \mathrm{~mm}$. The average size of the pearl millet grains was calculated from randomly selected 10 grain samples.

Geometric Mean Diameter: The geometric mean diameter was calculated by using the relationship (Mohesenin, 1986) ${ }^{[7]}$. Geometric mean diameter, $\mathrm{Dm}=[\mathrm{LBT}]^{1 / 3}$

Where, $\mathrm{L}=$ longest intercept (Length), $\mathrm{B}=$ longest intercept normal to $\mathrm{L}$ (Width) and $\mathrm{T}=$ longest intercept normal to $\mathrm{L}$ and B (Thickness)

Sphericity: The sphericity is used to describe the shape of the grain. The sphericity was calculated using the relationship (Mohesenin, 1986) ${ }^{[7]}$.

Sphericity, $\Phi=\mathrm{Dm} / \mathrm{L}$

Where, $\mathrm{Dm}=$ Geometric mean diameter and $\mathrm{L}=$ longest intercept (Length).

True Density: $50 \mathrm{ml}$ of toluene was taken in a measuring jar. A known weight of grain sample was poured to the measuring jar and rise in the toluene level was recorded. The true density of the grain was calculated by using the following formula (Mohsenin, 1986) ${ }^{[7]}$

True density, $\mathrm{kg} / \mathrm{m}^{3}=\frac{\text { Weight of grains }(\mathrm{kg})}{\text { Volume of grains excluding void space }\left(\mathrm{m}^{3}\right)}$

Bulk density: Bulk density was determined by using a container of known volume. The sample was taken into the container for the known volume and weighed. The bulk density was determined using the formula (Mohsenin, 1986) [7]

Bulk density, $\mathrm{kg} / \mathrm{m}^{3}=\frac{\text { Weight of grains }(\mathrm{kg})}{\mathrm{V} \text { Volume of berries including pore space }\left(\mathrm{m}^{3}\right)}$

Porosity: Porosity of sorghum grains was calculated from the bulk density and true density values (that were found earlier) by using the following formula (Mohesenin, 1986) ${ }^{[7]}$ :

Porosity, $\%=1-\frac{\text { Bulk density }}{\text { True density }} \times 100$

Weight of 1000 grains: One thousand grains were randomly selected and weighed using an electronic balance with an accuracy of $0.1 \mathrm{~g}$. Ten replications were weighed and the mean weight of one thousand grains was calculated.

\section{Frictional Properties}

Co-efficient of friction: Coefficient of friction was determined against three material surfaces namely steel sheet, wooden and galvanised iron sheet by surface method. The static angle of friction was recorded when the grain just began to slide on the test surface (Mohsenin, 1986) ${ }^{[7]}$.

Angle of repose: Angle of repose is the angle between base and slope of the cone formed on a free vertical fall of grains on to a horizontal plane. It was determined by following the 
procedure described by Sahay and Singh (2001) ${ }^{[13]}$. It was found by measuring the height $(\mathrm{H}, \mathrm{mm})$ and diameter $(\mathrm{D}$, $\mathrm{mm}$ ) of the grains heaped in natural piles by using the expression;

Angle of repose, $\theta($ degree $)=\tan -{ }^{1}[2 \mathrm{H} / \mathrm{D}]$

Aerodynamic properties: Aerodynamic properties of agricultural products are important and required for design of air conveying systems and the separation equipment (Sahay and Singh, 1994) ${ }^{[14]}$.

Terminal velocity: Terminal velocity is required to decide the velocity of winnowing air blown to separate a lighter material (Sahay and Singh, 1994) ${ }^{[14]}$. Terminal velocity is equal to air velocity at which the particle remains in suspended state in a vertical pipe. In this study, only terminal velocity of sorghum was measured using an air column. For each test, a sample was dropped into the air stream from the top of the air column and air was blown up the column to suspend the material in the air stream. The air velocity near the location of the sample suspension was measured by digital anemometer having a least count of $0.1 \mathrm{~m} / \mathrm{s}$ (Gharibzahedi et al., 2010a) ${ }^{[5]}$.

\section{Results and Discussion}

The results of the physical properties are presented in Table 1. The mean of individual pearl millet length, width and thickness were 3.522, 2.590 and $2.100 \mathrm{~mm}$, respectively. The values of length, width and thickness of the grains varied from $3.200-1.090 \mathrm{~mm}, 2.390-2.930 \mathrm{~mm}$ and $1.860-2.420 \mathrm{~mm}$. The average geometric mean diameter was $2.664 \mathrm{~mm}$ and it varied between $2.511-2.818 \mathrm{~mm}$. The projected area of the particle is used for the measurement of the sphericity. The sphericity values observed were in the range of $0.676-0.878$ and the mean sphericity value is 0.755 The average thousandgrain weight was $9.896 \mathrm{~g}$. The bulk density and true density were in the range $820.140-878.300 \mathrm{~kg} . \mathrm{m}-3$ and 1265.125$1269.125 \mathrm{~kg} . \mathrm{m}-3$ respectively. The mean of bulk density and true density were $852.644 \mathrm{~kg} . \mathrm{m}-3$ and 1267.236 kg.m-3 respectively.

Table 1: Physical Properties of Pearl millet

\begin{tabular}{|c|c|c|c|c|c|c|}
\hline Property & No. of observation & Minimum Value & Maximum Value & Mean & SD & C.V \\
\hline Moisture content (\%wb) & 10 & 8.920 & 9.150 & 9.066 & 0.0869 & 0.9586 \\
\hline Length (mm) & 10 & 3.200 & 4.090 & 3.522 & 0.3099 & 0.0880 \\
\hline Width (mm) & 10 & 2.390 & 2.930 & 2.590 & 0.1545 & 0.0596 \\
\hline Thickness (mm) & 10 & 1.860 & 2.420 & 2.100 & 0.2092 & 0.0996 \\
\hline Geometric mean diameter (Dm) & 10 & 2.511 & 2.818 & 2.664 & 0.1045 & 3.9238 \\
\hline Sherisity $\phi$ & 10 & 0.676 & 0.878 & 0.755 & 0.0680 & 9.0158 \\
\hline True Density (kg.m3) & 10 & 1265.125 & 1269.125 & 1267.236 & 1.5032 & 0.1186 \\
\hline Bulk Density (kg.m3) & 10 & 820.140 & 878.300 & 852.644 & 18.1519 & 2.1289 \\
\hline Weight of 1000 grains (g) & 10 & 9.340 & 10.470 & 9.896 & 0.3551 & 0.0359 \\
\hline
\end{tabular}

The results of frictional properties are shown in table 2 . The mean value of angle of repose of millet was $45^{\circ}$. The angle of repose is important for determining the maximum angle of a pile of grain in the horizontal plane, and is important in the filling of a flat storage facility. The average values of static coefficient of friction against steel, galvanized iron sheet and wooden plate were $0.378,0.422$ and 0.426 , respectively.

Table 2: Frictional Properties of Pearl millet

\begin{tabular}{|c|c|c|c|c|c|c|}
\hline Property & No. of observation & Minimum Value & Maximum Value & Mean Value & Std Deviation & C.V \\
\hline Angle of Repose & 10 & 35 & 40 & 38 & 2.054805 & 0.054 \\
\hline \multicolumn{7}{|c|}{ Static coefficient of sorghum } \\
\hline Steel & 10 & 0.33 & 0.41 & 0.378 & 0.026 & 0.069 \\
\hline GI & 10 & 0.36 & 0.46 & 0.422 & 0.033 & 0.079 \\
\hline Wooden & 10 & 0.39 & 0.48 & 0.426 & 0.031 & 0.072 \\
\hline
\end{tabular}

The aerodynamic property measured was ranging from 2.33 to $2.56 \mathrm{~m} / \mathrm{s}$. The mean value was $2.478 \mathrm{~m} / \mathrm{s}$ (Table 3 ).

Table 3: Aerodynamic Property of Pearl millet

\begin{tabular}{|c|c|c|c|c|c|}
\hline No. of observations & Minimum Value & Maximum Value & Mean Value & Std Deviation & C.V \\
\hline 10 & 2.33 & 2.56 & 2.478 & 0.085219 & 0.034 \\
\hline
\end{tabular}

\section{Conclusion}

The engineering properties of pearl millet were measured at $9.066 \%$ (w.b). The mean of individual pearl millet length, width and thickness were 3.522, 2.590 and $2.100 \mathrm{~mm}$, respectively. The average value for geometric mean diameter, sphericity, thousand grain weight, bulk density and true density were $2.664 \mathrm{~mm}, 0.755,9.896 \mathrm{~g}, 852.644 \mathrm{~kg} . \mathrm{m}-3$ and $1267.236 \mathrm{~kg} . \mathrm{m}-3$ respectively. The mean value of angle of repose of millet was $45^{\circ}$. The average values of static coefficient of friction against steel, galvanized iron sheet and wooden plate were $0.0 .378,0.422$ and 0.426 respectively. The mean value of aerodynamic property was found $2.478 \mathrm{~m} / \mathrm{s}$.
These properties can be used for design of equipment for handling and processing of the sorghum.

\section{References}

1. Balsubramanian S, Viswanathan R. Influence of moisture content on physical properties of minor millets. J Food Sci technol. 2010; 47(3):279-284.

2. Board on Science and Technology for International Development; Office of International Affairs; National Research Council, 1996-02-14. "Pearl Millet: Subsistence Types". Lost Crops of Africa: Volume I: Grains. Lost Crops of Africa. 1. National Academies Press. p. 108. ISBN 978-0-309-04990-0. Retrieved 2007-11-07. 
3. Enhancing food security in Namibia through value-added products. Council for Scientific and Industrial Research. March 2003. Archived from the original on 6 December 2005. Retrieved 4 March 2012.

4. Fuller DQ. African crops in prehistoric South Asia: a critical review. in Neumann, K., Butler, A., Kahlheber, S. (ed.) Food, Fuel and Fields. Progress in Africa Archaeobotany. Africa Praehistorica 15 series. Cologne: Heinrich-Barth-Institut, 2003, 239-271.

5. Gharibzahedi SMT, Mousavi SM, Moayedi A, Taheri Garavand A, Alizadeh SM. Moisture-dependent engineering properties of black cumin (Nigella sativa L.) seed. Agricultural Engineering International: CIGR Journal. 2010b; 12(1):194-202.

http://www.holidaytravel.com.na/index.php?fArticleId=2 22

6. Manning, Katie, Ruth Pelling, Tom Higham, Jean-Luc Schwenniger, Dorian Q Fuller. 4500-year-old domesticated pearl millet (Pennisetum glaucum) from the Tilemsi Valley, Mali: new insights into an alternative cereal domestication pathway. Journal of Archaeological Science. 2010; 38(2):312-322.

7. Mohsenin NN. Physical Properties of Plant and Animal Materials, 2nd edition. Gordon and Breach Science Publishers, New York, 1986

8. Ojediran JO, Adamu MA, Jim DL. Some physical properties of Pearl millet (Pennisetum glaucum) seeds as a function of moisture content. Afr. J. Gen. Agric. 2010; $6(1)$.

9. Millet. Consultative Group on International Agricultural Research.

10. Munyaradzi, Makoni (29 August 2013). "Biofortified pearl millet 'can combat iron deficiency'". SciDev Net. Retrieved 29 August 2013.

11. Olukhu SI, Nwuba ETU. Some physical and aerodynamic properties of cowpea seeds, Hulls and stalks. Journal of Engineering and Applied Sciences. 2000; (1):35-43

12. Ramappa KT, Batagurki SB, Karegoudar AV, Shanrnakumar H. Study on physical properties of finger millet. Inter J Agric Engg. 2011; 4(1):13-15.

13. Sahay, Singh. Unit operations of Agricultural processing. Vikas Publishing house Pvt Ltd, New Delhi, 2001.

14. Sahay, Singh. Unit operations of Agricultural processing. Vikas Publishing house Pvt Ltd, New Delhi, 1994.

15. Singh KP, Mishra HN, Saha S. Moisture-dependent properties of barnyard millet grain and kernel. J Food Engg. 2010; 96:598-606

16. Singh KP, Mishra HN, Saha S. Moisture-dependent properties of barnyard millet grain and kernel. J Food Engg., 2010; 96:598-606.

17. Swami SS, Swami SB. Physical properties of finger millet (Eleusine coracana) International Journal of Agricultural Engineering. 2010; 3(1):156-160

18. Sorghum and millet in human nutrition. Food and Agriculture Organization of the United Nations, 1995. 